\title{
Age as a criterion of value for tangible cultural heritage objects under Russian law
}

\author{
Maria A. Aleksandrova
}

For citation: Aleksandrova, Maria A. 2020. Age as a criterion of value for tangible cultural heritage objects under Russian law. Pravovedenie 64 (1): 176-183.

https://doi.org/10.21638/spbu25.2020.114

\begin{abstract}
UNESCO's activities are dedicated to the conservation of both intangible and tangible cultural heritage. One of the most difficult issues in constructing a system for the protection of tangible cultural heritage objects is the criteria for identifying objects as cultural heritage. Obviously, it takes time to assess the cultural or historical value and significance of a tangible object. In most cases, granting the status of a cultural heritage object is assigned much later than its creation. However, international acts also do not contain specific requirements for how old a particular object should be in order to qualify it as an object of cultural heritage. UNESCO's practice is known for several cases of adding to the World Heritage List relatively young sites. The Russian Cultural Heritage Object Act (2002), along with the laws of some other countries, establishes a specific age (40 years) that any object must reach in order to become a cultural heritage object. An exception is made only for memorial apartments and buildings (they can be attributed as objects of cultural heritage immediately after the death of famous personalities) and for objects of archeology (they must be at least 100 years old). This rule of law is mandatory, which means that it does not make other exceptions to the rule of 40 years. Such a rule of law significantly distinguishes the Russian approach from foreign legislation. On the one hand, such regulation may negatively affect the possibility of protecting outstanding objects from the late Soviet and early new Russian period. On the other hand, the approach of granting the status of cultural heritage objects to many relatively new objects can negatively affect urban development. The author proposes to evaluate and review this provision of law in order to find the optimal balance of public and private interests.

Keywords: UNESCO, cultural heritage object, age of cultural heritage object, tangible cultural heritage, public and private interests, cultural heritage protection.
\end{abstract}

\section{International law criteria in brief}

It is known that the international community realized the need for legal protection of the intangible cultural heritage much later than the need to protect tangible cultural and natural heritage ${ }^{1}$. However, despite the relatively long history of international legal protection of tangible cultural heritage ${ }^{2}$, many national legal systems are still searching for the

Maria A. Aleksandrova - PhD in Law, Associate Professor, St. Petersburg State University, 7-9, Universitetskaya nab., St. Petersburg, 199034, Russian Federation; m.aleksandrova@spbu.ru

1 The first universal international act dedicated to the safeguarding of the intangible cultural heritage - the Convention for the Safeguarding of the Intangible Cultural Heritage was adopted in 2003 (hereinafter: the 2003 Convention). The Russian Federation has not yet acceded to the 2003 Convention.

2 It's well known that the idea of the full protection of the tangible cultural and natural heritage was most fully expressed in the 1972 Convention for the Protection of the World Cultural and Natural Heritage. Nevertheless, the history of international legal protection of material cultural heritage in its most general form dates back to the 30s of the last century, when the prominent Russian artist and graduate of the law faculty of St. Petersburg University, Nikolai Roerich, initiated the adoption of an international act on the protection of cultural property - The Treaty on the Protection of Artistic and Scientific Institutions and Historic Monuments of April 15, 1935 (Roerich Pact). Roerich Pact is an inter-American treaty.

(c) St. Petersburg State University, 2021 
most beneficial legal solutions. Specific legal mechanisms for the protection of tangible cultural heritage remain imperfect in many national legal systems. Thus, one of the most sensitive issues is the criteria for attributing objects as tangible cultural heritage. Among these criteria, the age of objects is highlighted, i. e. the period of time that must pass from the moment of creation of the object to the legal possibility of identifying the object as tangible cultural heritage.

At the level of international legal acts, the criteria for identifying objects as tangible cultural heritage are formulated very generally. The 1972 Convention for the protection of the world cultural and natural heritage of UNESCO (hereinafter referred to as the Convention $)^{3}$ is dedicated to the protection of tangible objects of extraordinary universal value for all mankind. However, the provisions of the Convention form the basis of the national legislation of most participating countries as the basic principles on which systems for the protection of objects of national significance are built. In Art. 1 of the Convention, cultural heritage refers to monuments and places of interest. In particular, monuments include works of architecture and other objects that have outstanding universal value from the point of history, art and science.

The Operational Guidelines for the Implementation of the World Heritage Convention (hereinafter referred to as the Guidelines) establish a complex multi - step mechanism for identifying objects and a multi - factor system of signs of cultural heritage objects, based on two criteria-integrity and (or) authenticity ${ }^{4}$. According to Par. 82 of the Guidelines, objects can be recognized as meeting the criterion of authenticity if their cultural value is truthfully and reliably expressed through a variety of features, including: form and design; materials and substances; use and functions; traditions, techniques and management systems; location and setting; language and other forms of intangible heritage; spirit and feelings; and other internal and external factors. According to Par. 88 of the Guidelines, integrity is a measure of the unity and soundness of natural and/or cultural heritage and its attributes. The establishment of the integrity criterion requires an assessment of the extent to which the object: includes all the elements necessary to express outstanding value; is of sufficient size to fully represent the features and processes that reflect the value of the object; suffers from adverse effects of economic development and/or abandonment.

At the same time, modern scientific literature draws attention to the fact that the concept of authenticity is not always identified with the concept of material identity. Moreover, for humanitarian and sometimes political reasons, there are proposals to abandon the authenticity criterion in favor of the continuity criterion in order to ensure that cultural heritage items that were destroyed, for example, during armed conflicts, but subsequently restored, can be included in the lists. The concept of integrity in such cases can be interpreted very broadly ${ }^{5}$.

In accordance with Par.1 Art. 1 of the Convention on the protection of the architectural heritage of Europe ${ }^{6}$, architectural heritage refers to the following types of real estate:

${ }^{3}$ Convention for the Protection of the World Cultural and Natural Heritage (Concluded in Paris on 16.11.1972). The document entered into force for the USSR on January 12, 1989. Available at legal database "Consultant Plus": http://www.consultant.ru (accessed 25.06.2021).

${ }^{4}$ Sections II. D and II. E of the Operational Guidelines for the Implementation of the World Heritage Convention. Adopted on June 30, 1977 by the World Heritage Committee. Last revised 2017. See also Appendix No. 4 to the Guide - Nar Document of Authenticity. Available at: https://kgiop.gov.spb.ru/media/ uploads/userfiles/2017/08/10/26_11_2013_4.pdf (accessed: 25.06.2020).

${ }^{5}$ See for example: Jokilehto $\mathrm{J}$. Considerations on authenticity and integrity in world heritage context // City\&Time. 2006. No. 2 (1). P. 1-16. Available at: http://www.ceci-br.org/novo/revista/docs2006/CT2006-44.pdf (accessed: 25.06.2020).

6 Convention for the Protection of the Architectural Heritage of Europe (ETS No. 121) (Concluded in the city of Granada on 03.10.1985. Entered into force for the USSR on March 1, 1991) // Legal database "Consultant Plus". Available at: http://www.consultant.ru (accessed 25.06.2021). 
monuments, complexes of buildings, and attractions. All the listed categories of objects that differ in their functionality and composition should be united by a common feature all of them must be of clear historical, archaeological, artistic, scientific, social, or technical interest. At the same time, the definition of clear interest at the supranational level is not given; such definition should be identified in the national legal order of the participating countries ${ }^{7}$.

As we can see, the peculiarity of all the features of cultural heritage objects that are enshrined at the international level is their extreme abstraction. The functions of filling the features of cultural heritage objects specified in international acts with formalized content are delegated to national legislators.

Special attention should be paid to the fact that international acts do not emphasize the age of an object as a self-contained criterion for attributing objects as the cultural heritage objects ${ }^{8}$. Thus, there is no direct correlation between the age of an object and its value in international legal acts.

\section{Russian legislation and practice}

Russian legislation has certain specifics regarding the definition of criteria for identifying objects as objects of cultural heritage. According to the provisions of Russian legislation, cultural heritage objects are a specific category of objects accepted for state protection under the procedure established by law.

In accordance with Art. 3 of The Cultural Heritage Objects Act of Russian Federation of 25.06.2002 No. 73 (hereinafter: the Cultural Heritage Act) ${ }^{9}$ the necessary features of cultural heritage items include the following: 1) objects must relate to real estate or other objects with historically related territories, works of painting, sculpture, decorative and applied art, objects of science and technology and other items of material culture; 2) objects must arise as a result of historical events; 3 ) objects must be of value from the point of view of history, archeology, architecture, urban planning, art, science and technology, aesthetics, ethnology or anthropology, social culture; and 4) objects must be evidence of epochs and civilizations, authentic sources of information about the origin and development of culture.

It is obvious that the Russian legislator, following international trends, uses criteria of both material ("immovable things", "objects of material culture") and non-material value of objects ("evidence of epochs and civilizations") as attributes of an object of cultural heritage. The Russian legislator also pays attention to the criterion of authenticity: cultural heritage objects must be authentic sources of information about culture ${ }^{10}$.

\footnotetext{
7 In this aspect the example of Great Britain is very remarkable. In British law on the protection of monuments, the term "interest" is actively used. Attention is drawn to the term "special architectural or historical interest", the presence of which can be recognized in relation to a building that has a very weak external visual quality (little external visual quality), but during the construction of which innovations in the field of materials or engineering were applied. See: Principles of Selection for Listed Buildings. November 2018. Available at: https://assets.publishing.service.gov.uk/government/uploads/system/uploads/attachment_data/file/757054/Revised_Principles_of_Selection_2018.pdf (accessed: 25.06.2020).

8 In the UNESCO practice there are cases when sites of a very small age were listed. So, the city of Brasilia, built in 1960, created using the ideas of Le Corbusier, was listed in 1987.

9 The Cultural Heritage Objects Act of Russian Federation of 25.06.2002 No. 73 // Legal database "Consultant Plus". Available at: http://www.consultant.ru (accessed 25.06.2021).

10 The concept of authenticity is also given in Art. 3.1.6 of The Russian Federation State Standard 55528-213 "Composition and content of scientific and design documentation for the preservation of cultural heritage objects. Monuments of history and culture" (hereinafter: Standard) as a determining factor in the value of the object of cultural heritage. However, it should be noted that the criteria of authenticity given in the Standard cannot be put by law enforcement bodies in substantiating their decisions for the following
} 
So, placing descriptions of all major signs of cultural heritage objects into the very beginning of the Cultural Heritage Act (Art. 3) should be considered as the legislator granting them a universal status - any object that applying for inclusion into the List of the revealed (newly identified) cultural heritage objects (hereinafter referred to as the Prelist), and then in the Unified State Register of cultural heritage objects (hereinafter referred to as the Register) must match the given criteria.

The implementation of the statutory procedures to identify new objects involves the progressive transformation of the legal regime of an ordinary object into a cultural heritage object (an object that has characteristics of object of cultural heritage $\rightarrow$ newly identified cultural heritage object $\rightarrow$ cultural heritage object). The stages of this process are as follows: 1) detection of the alleged signs (features) of the object of cultural heritage in the object (Par. 1-2 Art. 16.1 of the Cultural Heritage Act) ${ }^{11}$; 2) organization by the State Cultural Heritage Protection Office (hereinafter referred to as the Protection Office) the initial check of the presence of these signs (Par. 3 Art. 16.1 of the Cultural Heritage Act) ${ }^{12}$; 3 ) the inclusion of an object which has signs of cultural heritage object in the Prelist (Par. 4 Art. 16.1 of the Cultural Heritage Act); 4) verification of value of the newly identified object by the State Historical and Cultural Expertise (hereinafter referred to as the Expertise) (Par. 1-2 Art. 18 of the Cultural Heritage Act); and 5) the inclusion of the identified cultural heritage object, which received a positive conclusion of Expertise, into the Register (Par. 3 Art. 18 of the Cultural Heritage Act).

From the moment of inclusion in the Prelist, the legal regime of the object changes significantly - it begins to be subject to the requirements of the Cultural Heritage Act for the preservation of the object; the rights of owners to use the object are significantly limited in the public interest. Further inclusion of the identified object in the Register leads to the final consolidation and detailing of the public restrictions regime.

Par. 12 Art. 18 of Cultural Heritage Act claims that the Register may include newly identified tangible cultural heritage objects that have been at least 40 years old since their origin or date of creation, or since the date of historical events which such objects are connected with. This "age limit rule" contains exceptions for two types of objects. Firstly, talking about memorial apartments and houses of outstanding people for the Russian culture, age period can be shortened - at any time after death of such people these objects could be attributed to be the cultural heritage objects. Secondly, in order for the objects of archaeological heritage to be included into the Register, the "age limit" of such objects is being increased regulatory - at least a hundred years should pass.

The given law expression about "age limit" of cultural heritage objects cause a number of questions in the area of law, politics and legal engineering.

At first, it is not quite clear if the "age limit" rule operate as obligatory for objects that go yet to the Prelist, but not to the Register, in other words - does the age matters to the identification (revealing) of the object?

reasons. Firstly, in accordance with the provisions of Art. 4 of the Law of the Russian Federation on June 29, 2015 No. 162-Ф3 "On Standardization in the Russian Federation", the specified Standard does not belong to the category of regulatory legal acts and is of a recommendatory nature. Secondly, the indication of authenticity as a determining factor in the value of objects of cultural heritage given in the Standard is not precise. As noted earlier, the Guidelines use not only a criterion of authenticity, but also a criterion of integrity of cultural heritage sites. In the Cultural Heritage Law, the concept of "value factors" of a cultural heritage object is missing. Thus, the definition of authenticity given in Standard can be considered as not entirely accurate arrangement of selected provisions of the Guidelines.

11 According to this norm, any person or organization can submit an application for identifying an object that has the features of a cultural heritage object.

12 Due to the federal structure of the state, in Russia there are three levels of the protection bodies Ministry of Culture of the Russian Federation, regional protection offices and local protection offices. 
Caselaw (that is still not so capable) answers confirmatively. In the existing acts, the courts rule that the requirement for the expiration of the 40-year period is a necessary condition for including an object not only in the Register, but also in the Prelist. Therefore, objects claiming to be included in the Prelist, must meet both the criteria specified in Art. 3 and Art. 18 of the Cultural Heritage Act. Special attention should be paid to the fact that Russian procedural legislation gives any individual the right to appeal to court against acts of cultural heritage protection office if such a person believes that these acts do not meet the requirements of the law.

Thus, in one of the appellate decisions of the Sverdlovsk regional court, the administrative plaintiff claimed that the order of the Protection Office to refuse to include the object in the Prelist was declared illegal. The claim was rejected on other grounds, but the decision, in particular, indicates the legality of the decision of the Protection office to refuse to include the object into the Prelist due to the fact that 40 years have not passed since the creation of the disputed object - a radio-television transmitting station ${ }^{13}$.

A similar position is given in the decision of the Balakhninsky City Court of the Nizhny Novgorod region, which indicates that the historical and cultural value of an object that has the characteristics of a cultural heritage object, for the purposes of inclusion in the Prelist, is determined by the following criteria: 1) compliance with the criteria defined in Art. 3 of the Cultural Heritage Act; and 2) compliance with the origin or date of creation, or the date of historical event which such object is connected with to the requirements defined in Art. 18 of the Law ${ }^{14}$.

The same goes to the position of the Saratov regional court in the case in which the administrative plaintiff went against the order of the Protection Office to include an object that had signs of cultural heritage in the list of identified cultural heritage objects (the Prelist). The claimant referred to the fact that the building was built in 1979, so, at the time of the decision to include it in the Prelist, less than 40 years had passed, which prevented the decision to include the building in the Prelist. The court, having agreed that the identified objects included in the Prelist must be older than 40 years, nevertheless, rejected the claim, since it was established that the building was not built in 1979, but in 1900, and that the disputed object is part of a group of buildings (architectural ensemble), built in the late $19^{\text {th }}$ century ${ }^{15}$.

Finally, one of the last cases where these rules were invoked took place in St. Petersburg. As it follows from the case file, several public organizations have applied to the Regional Protection Office of St. Petersburg with a request to identify an object. The Protection Office refused to include it in the Prelist, referring to the fact that 40 years have not yet passed from the construction of the object. The Office's refusal to include the object in the Prelist was appealed by an interested individual in court. The District court during the hearing established the exact date of the object's construction and dismissed the administrative action, citing the fact that at the time of the trial, the 40-year period has not expired. The decision was appealed to a higher instance, and the Court of Appeal - City Court of St. Petersburg - agreed with the decision of the lower instance ${ }^{16}$.

${ }^{13}$ Court of Appeal of the Sverdlovsk Region Case No. 33a-12702/2018 of 02.08.2018 ("Ural Chronotope Case").

${ }^{14}$ Balakhninsky City Court (Nizhny Novgorod region) Case No. 2a-462/2017 of 03/13/2017 ("House of Culture of the Transport Administration of the Chernoramensky Torfotrest Case").

15 Saratov Regional Court case No. 3a-49/2016 of September 20, 2016 ("Depot, ensemble of the railway station 'Pokrovsk'”).

16 Kuibyshevsky District Court of St. Petersburg Case No. 2a-3302/19 of 11/15/2019; St. Petersburg City Court of Appeal 17.06.2020 ("Sports and Concert Complex 'Peterburgsky"). This case received a significant public outcry due to the fact that the building was hastily demolished during the trial. Thus, the refusal to provide temporary legal protection led to the very sad consequences - destruction of the object. 
It seems that the given position of the courts regarding the "age limit" for inclusion of objects in the Prelist cannot be supported for the following reasons.

Firstly, in Par. 1 Art. 16.1 of the Cultural Heritage Act it is stated that the Regional State Cultural Heritage Protection Office should undertake work to identify and make governmental accounting of objects which have the characteristic of cultural heritage from the Act. Therefore, the characteristics that an object of cultural heritage must possess to be included in the List of identified objects are determined only on the basis of Art. 3 of the Act.

Secondly, Par. 12 Art. 18 of the Act directly refers to the identified objects. A literal interpretation of this rule leads to the conclusion that the 40-year period should expire by the time the decision is made to include the newly identified object in the Register.

Finally, the same conclusion is reached by an attempt of teleological interpretation of the above legal norms. Russian legal system provides for a comprehensive and multistage system for identifying cultural heritage objects. The purpose of this system is to provide well-timed and omnidirectional protection to objects that have a proven public interest in their preservation. Since the society is interested in the most effective identification of such objects, the organization of work on their identification, according to the Russian law, can be carried out not only by authorized state bodies, but also by any interested individuals or legal entities.

Moreover, in contrast with some examples of foreign regulation, the Russian Regional State Cultural Heritage Protection Office cannot ignore the appropriate form of requests from concerned parties to identify objects - within the time limit established by law, the protection body must organize work to establish the historical and cultural value of the object. If the value of an object is previously confirmed, the Regional State Cultural Heritage Protection Office must decide to include it in the List of identified objects and from this moment the protection must be given.

In accordance with the Art. 18 of the Cultural Heritage Act, the decision to include an identified object in the Register or to refuse to include should be made on the basis of the Governmental historical and cultural expertise and must be taken by the relevant body within a period of no more than one year from the date of the decision to include an object that has the characteristics of a cultural heritage object in the List of identified objects (Prelist). Thus, it seems that during the year, an object that has the characteristics provided in Art. 3 of the Act (from the point of view of the Russian Regional State Cultural Heritage Protection Office) can wait before the expiration of the 40-year period.

In our opinion, this interpretation of the relevant provisions of the Cultural Heritage Act most fully reflects the very idea of providing preliminary protection to identified cultural heritage objects.

The list of exceptions to the 40-year rule, which was given earlier, is obviously mandatory - only memorial apartments and houses can become cultural heritage objects before the specified period. We believe that this approach of the legislator is unjustified from the political and legal point of view, and, therefore, needs to be reviewed.

As it was mentioned there are no clear requirements in international legal acts for the age of monuments as mandatory markers of the value of objects. Foreign experience also indicates either the complete absence of an age criterion, or an open list of exceptions to the rule on a certain age limit.

For example, in Germany, the protection of cultural heritage is assigned to the management of land. None of the modern laws of the federal lands provides for a specific age, after reaching which a particular object can be considered as a monument. This kind of age limit existed in the past - in the Prussian legislation of the early $20^{\text {th }}$ century. Since the middle of the last century, such restrictions have been abandoned. In the legislation of several lands (Bavaria, Saxony-Anhalt), when defining the term monument, it is specified that this regime is given exclusively to objects from the past, but it is not specified at what 
point the "past" should begin. In practice, objects that have taken relatively little time from the origin are rarely placed under state protection. In such cases, the historical and cultural expertise must prove that the object is a striking example of a bygone era (for example, the new building of the Bundestag in Bonn after the transfer of the capital to Berlin, etc. $)^{17}$.

The United States has a national register of historic objects worthy of preservation, created under the Historic Preservation act of 1966. At the same time, each object nominated for inclusion in this register is evaluated for compliance with the established criteria (criteria for evaluation). The guidelines for applying these criteria allow for inclusion in the national register of objects that have been established for at least 50 years ago and also if they meet special requirements called "criteria considerations". However, the 50-year mark is not so compulsory. In fact, the age of an object is determined only by the number of criteria that must be taken into account ${ }^{18}$.

As we can see, the requirements of Russian legislation to the age limit of cultural heritage objects stand out from both in continental legal systems and in common law countries due to their unjustified imperativeness. The purpose of such legislative regulation is not quite clear. It is obvious that under certain conditions and in exceptional cases, objects created not long time ago may also need effective protection by giving them the legal regime of cultural heritage objects. We consider it to be a necessity to review Par. 12 Art. 18 of the Cultural Heritage Act in terms of establishing an open list of exceptions to the general rule on the 40 -year minimum age of an object required for its inclusion in the Register.

\section{References}

Davydov, Dimitrii, Hönes, Ernst-Rainer, Ringbeck, Birgitta, Stellhorn, Holger. 2018. Denkmalschutzgesetz Nordrhein-Westfalen. Kommentar. 6. Aufl. Wiesbaden. Kommunal- und SchulVerlag.

Davydov, Dimitrii. 2018. Zu nah an der Gegenwart. Die Zeitgrenze als Merkmal des Denkmalbegriffs. Denkmalpflege als kulturelle Praxis. Zwischen Wirklichkeit und Anspruch, Hrsg. Niedersächsisches Landesamt für Denkmalpflege: 64-68. Hannover, C. W. Niemeyer Buchverlage GmbH.

Jokilehto, Jukka. 2006. Considerations on authenticity and integrity in world heritage context. City \& Time 2 (1): 1-16. Available at: http://www.ceci-br.org/novo/revista/docs2006/CT-2006-44. pdf (accessed: 25.06.2020).

Received: July 1, 2020

Accepted: December 23, 2020

\section{Возраст как критерий ценности объекта культурного наследия по российскому праву}

\section{М. А. Александрова}

Для цитирования: Aleksandrova, Maria A. Age as a criterion of value for tangible cultural heritage objects under Russian law // Правоведение. 2020. Т. 64, № 1. С. 176-183.

https://doi.org/10.21638/spbu25.2020.114

17 See for example: Davydov D., Hönes E.-R., Ringbeck B., Stellhorn H. Denkmalschutzgesetz Nordrhein-Westfalen. Kommentar. 6. Aufl. Wiesbaden: Kommunal- und Schul-Verlag, 2018; Davydov D. Zu nah an der Gegenwart. Die Zeitgrenze als Merkmal des Denkmalbegriffs // Denkmalpflege als kulturelle Praxis. Zwischen Wirklichkeit und Anspruch / Hrsg. Niedersächsisches Landesamt für Denkmalpflege. Hannover: C. W. Niemeyer Buchverlage GmbH, 2018. S. 64-68.

18 National Register Bulletin. Available at: www.nps.gov/subjects/nationalregister/upload/NRB-15_ web508.pdf (accessed: 15.06.2020). 
Деятельность ЮНЕСКО посвящена сохранению как нематериального, так и материального культурного наследия. Одной из наиболее сложных проблем построения системы охраны является критерий отнесения объектов к материальному культурному наследию. Очевидно, что для оценки культурной или исторической ценности и значения объекта требуется время. В большинстве случаев придание объекту культурного наследия специального правового режима существенно отстоит по времени от момента его создания. Международные конвенции не содержат конкретных требований к возрасту объекта для квалификации его в качестве памятника. Практика ЮНЕСКО знает случаи включения в Список всемирного наследия относительно молодых объектов. Российский закон об объектах культурного наследия (2002 г.), наряду с законами некоторых других стран, устанавливает конкретный возраст (в России - это 40 лет), которого должен достичь объект, чтобы стать объектом культурного наследия. Исключение составляют лишь мемориальные квартиры и здания (они могут быть отнесены к объектам культурного наследия сразу после кончины известных личностей) и объекты археологии (им должно быть не менее 100 лет). Эта норма сформулирована как жесткое императивное правило, не знающее иных исключений, что существенно отличает российский подход от зарубежных аналогов. С одной стороны, такое регулирование может поставить под удар охрану выдающихся объектов позднесоветского периода, с другой - появление механизма постановки под охрану значительно числа относительно новых объектов культурного наследия способно негативно повлиять на развитие городов. Автор предлагает осуществить ревизию норм российского законодательства о возрастном критерии объектов культурного наследия с целью поиска оптимального баланса общественных и частных интересов.

Ключевые слова: ЮНЕСКО, объект культурного наследия, возраст объекта культурного наследия, памятник истории и культуры, публичные и частные интересы, охрана культурного наследия.

Статья поступила в редакцию: 1 июля 2020 г. Рекомендована в печать: 23 декабря 2020 г.

Александрова Мария Александровна - канд. юрид. наук, доц., Санкт-Петербургский государственный университет, Российская Федерация, 199034, Санкт-Петербург, Университетская наб., 7-9; m.aleksandrova@spbu.ru 